\title{
Life to the Full: Sustaining the Catholic Curriculum
}

\author{
David Fincham
}

check for updates

Citation: Fincham, David. 2021. Life to the Full: Sustaining the Catholic Curriculum. Religions 12: 983. https://doi.org/10.3390/rel12110983

Academic Editor: Eamonn Conway

Received: 23 July 2021

Accepted: 4 October 2021

Published: 10 November 2021

Publisher's Note: MDPI stays neutral with regard to jurisdictional claims in published maps and institutional affiliations.

Copyright: (C) 2021 by the author. Licensee MDPI, Basel, Switzerland. This article is an open access article distributed under the terms and conditions of the Creative Commons Attribution (CC BY) license (https:/ / creativecommons.org/licenses/by/ $4.0 /)$.
Institute of Education, St Mary's University, London TW1 4SX, UK; david.fincham@stmarys.ac.uk

\begin{abstract}
Catholic schools. has articulated There are concerns that the curriculum of Catholic schools has been increasingly dominated by pressures to conform to a programme of education legitimised by an intrusive secular state and designated as a 'national curriculum'. Accordingly, the curriculum of Catholic maintained schools is regulated within a standardised framework that is directed by government. Contentiously, it has been asserted that, as a result, the curriculum in Catholic schools in England has effectively been 'de-Catholicised'. This claim has been contested. For example, it is maintained that the matter is more nuanced than this and the situation cannot be interpreted in such an unequivocal way. However, it might well be asked: what should a Catholic curriculum look like? In the face of this question, leaders in Catholic schools are encouraged to consider renewing and restoring a distinctive curriculum by permeating it systematically with the principles of Catholic social teaching. Ultimately, the writer argues, the curriculum of Catholic schools should provide students with an understanding of the teachings of Jesus Christ.
\end{abstract}

Keywords: Catholic education; distinctive curriculum; formation; ethos; worldview; National Curriculum; secularisation

\section{Introduction}

One of the most important debates in education today concerns what children should learn in schools. For many years now, I have reflected on this specifically in relation to the curriculum that is provided in Catholic schools. There are a number of questions that have occurred to me. For example, what do we understand by the curriculum? How do we define it? With the vast ocean of knowledge that is nowadays instantly accessible through the internet, what should children learn when they are at school? What is most important? Catholic schools have a distinctive religious character and offer a philosophy of education that is based on faith. But what, if anything, is it that marks the distinctiveness of the curriculum of a Catholic school? Is the curriculum in a Catholic school different from a curriculum in any other kind of school? If so, what should it look like? If a curriculum conveys values, what do we mean by values?

This is a considerable range of questions to begin this enquiry. However, whilst the subject of the curriculum has been examined in a vast range of literature, which can be traced at least as far back as Plato in The Republic, the focus of this paper will be to consider the curriculum of Catholic schools. To start with, it is interesting to note that a broad perspective of the curriculum in a Catholic school was outlined by Pope Benedict XVI (2010, p. 30) during his papal visit to Britain in September 2010, when he reflected:

... always remember that every subject you study is part of a bigger picture. Never allow yourselves to become narrow. The world needs good scientists, but a scientific outlook becomes dangerously narrow if it ignores the religious or ethical dimension of life, just as religion becomes narrow if it rejects the legitimate contribution of science to our understanding of the world. We need good historians and philosophers and economists, but if the account they give of human life within their particular field is too narrowly focused, they can lead us seriously astray. 
The implication is that a school curriculum should be regarded more broadly than a set of academic, empirical and artificially-designed subjects of study but should include religious, moral and spiritual aspects of human life. In other words, a curriculum should be imbued with values that reflect a synthesis of faith and culture. It reflects a holistic and integrated approach to education. This is not a perspective that is universally accepted, though, and it has been contested by an aggressive campaign opposing faith schools. Thus, there is a view that the curriculum should not include a religious or faith dimension. The National Secular Society (2021), for example, contends:

We don't think schools should be organised around religious identities or used to promote religious worldviews. ... religion is still deeply ingrained across the UK's education systems. Academies and 'free schools' have only increased the opportunities for religious groups to gain control of schools (https: / www. secularism.org.uk/education/ accessed on 30 March 2021)

The question arises, however, whether it is possible for a curriculum to be as value free or 'objective' as this argument would imply. Clearly, the curriculum is a complex and contentious subject, which is open to a wide range of interpretations. The idea of the curriculum is not as straightforward as it might at first appear. It would be helpful, therefore, to consider what is meant by 'the curriculum'.

\section{What Is Meant by 'the Curriculum'?}

Much has been written about the curriculum in schools. (Kelly 2009; Kerr 1968; Lawton 1989, 2000; Pring 1976; Stenhouse 1978; Tyler 1949) The word 'curriculum' itself derives from a Latin word for course: currere 'to run'. Cognate words, such as 'courir' (French) and 'correr' (Spanish), meaning 'to run', can be found in modern European languages today. In fact, the word 'curriculum' itself derives from the Latin word for a 'race course,' as in a lap of a stadium, especially in the context of chariot races in ancient Rome. It is only in more recent centuries that it has come to be applied to a 'course of study'. Lawton (2000, p. 25), for example, claims that

We talk of the curriculum as who teaches what to whom for what purpose, and who decides?

However, there is no one single definitive construction of the curriculum. It would appear that it is not fixed and static but reflects a selection of knowledge that is deemed to be appropriate at a particular time. The modern parable of the sabre-tooth tiger curriculum (Benjamin 1939) ${ }^{1}$ exemplifies that, if the curriculum is to remain relevant, the range of knowledge and skills selected for the curriculum must be adapted according to the needs of society. Indeed, the way in which a curriculum is subject to revision according to social and technological changes can be demonstrated by the experience of schools in the last fifty years, when subjects such as information technology, computer studies and design technology have been introduced to the curriculum, and food technology is now open for boys as well as girls to study.

As I shall discuss, however, a selection of knowledge, though important, is only one aspect of the curriculum. The design of the curriculum is determined by various factors and considerations, cultural, social, ideological and economic. These may include both 'instrumental' aspects of the curriculum, which represent, for example, academic progress, examination qualifications and career prospects, and 'expressive' aspects of the school in terms of the transmission of values, which enhance cohesion and consensus. All of these perspectives are relevant but, ultimately, the curriculum reflects the system of values promoted by a school. I shall return to the question of values later, but before I do, and by way of example, I shall illustrate the increasing centralisation in education in many countries around the world. In this context, it would be pertinent to consider the context of the introduction and development of the National Curriculum in England and Wales in the late 1980s. 


\section{The National Curriculum}

In one way or another, a national curriculum has been an evolving part of schooling in many nations across the world. France, Italy, Japan, the Netherlands, New Zealand, Norway, Portugal, Singapore and Spain can be counted amongst the countries that have adopted a National Curriculum. Scotland has developed its own National Curriculum (Education Scotland 2004). Ireland, too, has a centralised education system where the curriculum is under the control of the national Ministry advised by the National Council for Curriculum and Assessment (NCCA). In the case of England and Wales, a National Curriculum was introduced in schools in 1988, and it has undergone a number of revisions since.

The introduction of the National Curriculum in England seems to have been inspired by the need to improve Britain's economic competitiveness. Its rationale was based on the premise that education should be informed by the views of consumers (employers and parents) and that market forces should be exploited in order to improve school effectiveness. In his speech at Ruskin College, Oxford, in 1976, the then Prime Minister, James Callaghan, began what came to be known as the 'Great Debate', in which he declared":

The goals of our education, from nursery school through to adult education, are clear enough. They are to equip children to the best of their ability for a lively, constructive, place in society, and also to fit them to do a job of work.

Not one or the other but both ... (Online: retrieved 19 May 2021)

Callaghan emphasised the importance of a well-educated population that would contribute to the social and economic well-being of the nation. This set in train events that would lead to the introduction of the National Curriculum in the Education Reform Act (ERA) of 1988.

In my own professional experience, of all the many changes that have taken place in education in England over the last forty years, it is the passing of the Education Reform Act (1988) that I consider to have been a watershed event. It marked a significant moment in the history of education in England. In my experience of education, it seems to me, in retrospect, to have been a critical and irreversible juncture. Before 1988, education in England was 'nationally organised and locally administered.' Until that time, other than the authority of examination boards, through their syllabuses, to direct the content of examinations at $16+$, educational provision for young people during the years of compulsory education was largely determined by local authorities or headteachers within individual schools.

From 1988, however, through the design and implementation of a centralised National Curriculum and the concomitant publication of school league tables based on examination results, the introduction of Local Management of Schools (LMS), and the establishment of a national inspection system, a radically changed environment for educational provision prevailed. Essentially, by devolving financial power to individual schools, which were modelled on small businesses, the Act sought to apply market-oriented, neo-liberal ${ }^{3}$ principles to education.

The Education Reform Act (1988) was the culmination of decades of anxiety about the nature and purpose of education provided for young people in England and the need for an agreed curriculum. It provided for the introduction of a National Curriculum, which defined the statutory parameters for the educational provision of maintained schools. Ending many years of what might be conceived as a devolved educational provision, the Act determined that the government should define the curriculum centrally, and that, to ensure that it was properly implemented, it would be appraised by a regular and rigorous system of inspection. It began a process by which educational policies would ultimately be determined by the Secretary of State for Education (Newsam 2013).

Whilst the National Curriculum did not apply to independent schools, the government ensured that all state schools in Local Education Authorities in England had a common curriculum for pupils aged 5-16, which removed responsibility for what was to be taught in schools away from schools to central government. The National Curriculum identified 
three core subjects (English, maths and science) and seven foundation subjects (history, geography, modern foreign languages, design and technology, art and design, music and physical education). Although there was not a specific provision for religious education within the National Curriculum, all maintained schools were expected to follow the National Curriculum requirements to teach a broad and balanced curriculum, which included religious education. All maintained schools, therefore, had a statutory duty to teach religious education.

The Education Reform Act (1988) set out the knowledge, skills and understanding that the government considered children and young people should be expected to acquire at school. It is interesting to note that the Education Reform Act (1988, clause 1.2) stipulates that:

The curriculum for a maintained school satisfies the requirements of this section if it is a balanced and broadly-based curriculum which-promotes the spiritual, moral, cultural, mental and physical development of pupils at the school and of society; and prepares such pupils for the opportunities, responsibilities and experiences of adult life.

Since 2015, though, free schools and academies have not been required to follow the National Curriculum, but educational provision still has to be broad and balanced and must include English, maths, science and religious education.

\section{Challenges for Catholic Education}

For maintained Catholic schools in England, these developments present a cause for anxiety. Catholic schooling is not just a secular curriculum with some religion lessons bolted on. The Catholic ethos should be more pervasive than that. It has been argued (Davis 1999, pp. 221-222) that Catholic schools have had to pay the price for adopting the National Curriculum insofar as it is

[a] restriction of their Catholicity to those features of school life where secular society is prepared to permit the manifestation of Catholic ideas-mainly worship, ethos and religious education ....

The implication is that, within a National Curriculum, religious education would become an isolated and exclusive component within the wider academic provision of the Catholic school, marginalised from the rest of the curriculum (Davis and Franchi 2013, p. 39).

Jamison (2013, p. 13) recounts that when he explained the British curriculum to a Catholic educator in America, the response was: 'Why would anybody in Britain bother running a Catholic school if the government determines the curriculum?' The implication is that, if a Catholic school is to offer a distinctive curriculum, its educational provision needs to articulate a more overtly Catholic perspective.

It has long been acknowledged that contemporary interpretations of the curriculum are not necessarily inimical to the Catholic worldview. Indeed, an intelligible Catholic philosophy of knowledge and pedagogy will always be open to new thinking and new practices. This is evident in the seminal Vatican II document on education, Gravissimum Educationis (Pope Paul VI 1965, n.11), which concedes that Catholic schools can be more effective

by employing up-to-date methods and aids [to] lead their students to more penetrating inquiry.

However, the introduction of the National Curriculum has presented significant challenges to the educational provision of Catholic schools. In his ground-breaking book, Catholic Schools: Mission, Markets and Morality, Grace (2002a), for example, expresses a concern that the Catholic school curriculum is increasingly subject to secular pressures that would potentially compromise the mission of Catholic schools.

He says (Grace 2001, p. 494) that the introduction of the National Curriculum with specified 'core subjects' threatens the integrity of notions of a relatively autonomous Catholic curriculum shaped by Catholic educational principles. 
The contention is that, following developments inaugurated by the Education Reform Act (1988), the curriculum provision in schools in England can now be characterised as a 'market curriculum'. This reflects an increasing emphasis within education on the promotion of economic development and international competitiveness. It implies, in effect, the commodification of knowledge and pedagogy. Pring $(2004$, p. 20) argues that the philosophy of the competitive market place is incompatible with the purposes of education. He observes that

The language of inputs and outputs, of value addedness, of performance indicators and audits, of product and productivity, of educational clients and curriculum deliverers, constitutes a new way of thinking about the relation of teacher and learner.

Eloquently describing the effects of these regulated priorities and the consequent 'depersonalisation' of schools, Pring (2020, p. 96) refers to 'the new managerial language' of 'deliverology' as an alternative form of pedagogy.

The curriculum of a Catholic school should offer more than this. The Sacred Congregation for Catholic Education (1977, n. 56) points out that knowledge is not to be considered as a means of material prosperity and success, but as a call to serve and to be responsible for others.

In contrast, the underlying philosophical discourse of the National Curriculum, shaped by the commercial and economic requirements of the government, are broadly secular and utilitarian. Grace (2002a, p. 206) discerns that Catholic schools, along with other schools in England and Wales, have been subjected to an intensified work and surveillance culture and this raises questions about what effect the new 'performativity' culture in schools is having upon the spiritual development of both teachers and students.

Commenting on the debate on school effectiveness, Grace (1998, p. 118) says:

the field [of school effectiveness research] remains vulnerable to the twin dangers of technical reductionism on the one hand and of ideological appropriation on the other.

There is a danger that a drive towards school effectiveness will lead to a culture in which the quality of education and student learning is measured exclusively by scientific objectivity. This implies a reductionist philosophy that conforms to prevailing demands of employers and parents in which the procurement of academic results predominates.

The curriculum offered by schools in England has also been characterised as being too heavily focused on the achievement of academic results, as exemplified in league tables, to the detriment of attainment in non-cognitive aspects of education. (Pring 2005, 2012) As a result, there is a tendency for intrinsic values of education that support the personal, social and spiritual development of young people to be marginalised. In this light, the introduction of the National Curriculum and the consequent marketisation of education raises a concern that the fundamental values that inform Catholic schools will be diluted and undermined. Thus, Holman (2013, p. 58) opines: It is especially important that the drive to climb higher up the league tables is kept in proportion lest the values of individualism and competition erode our collective commitment to the common good...

Otherwise, as Grace (1997, p. 161) perceptively points out:

As Catholic schools respond to contemporary market values in education and to the issues of institutional survival which they generate, a conflict of values is likely to result.

This conflict raises a number of important questions concerning the integrity and authenticity of the curriculum offered by Catholic schools. Grace (2002b, p. 7) therefore asks:

Can a legitimate balance be found between Catholic values and market values or will market forces in education begin to compromise the integrity of the special mission of Catholic schooling? 
Christian values that advocate the virtues of faith, hope and love may often be regarded as counter-cultural. These values challenge prevailing attitudes in education where the role of the teacher in schools has become constrained by the demands of Ofsted, the strictures of target-setting, the prevalence of managerialism and the scrutiny of measurable performance as evidenced by examination results. As a result, Gleeson (2015, p. 147), writing in the Australian context, observes that the emphasis is on measurable outputs, employment-related skills and competences, consumer choice, increased state control over curriculum content and assessment and standardised testing.

Summed up in a phrase attributed to St Francis, 'Be careful what you measure or you may end up valuing only what you measure.'

Grace (2002b, p. 7) warns that these developments represent existential challenges for Catholic schooling. Consequently, if the culture of the market place prevails, Catholic schools will face a challenge which:

at its worst, involves the commodification of education, the marketisation of school cultures and processes, and the celebration of an ethic of individual and autonomous success, regardless of the fate of other schools. These developments do not articulate easily with Catholic values, where spiritual and moral culture is given precedence over material success, where education is seen as a service and not a product, and where notions of the common good and of the well-being of community institutions take precedence over self-interest. ... Can Gospel values survive in the face of a more direct relationship with the market place and education?

Arthur (2007, p. 14), too, argues that a culture that treats knowledge as a product for consumption, in which there is an overemphasis on results based on targets, tests and tables does not sit easily with Catholic values. Whilst the National Curriculum must lay emphasis on the needs of the economy, the curriculum of the Catholic school is also concerned about the common good. Arthur (2007, p. 13), therefore, contends that the influence of the Catholic Church on the curriculum of Catholic schools in England and Wales has been diluted. This situation has been further exacerbated by the introduction of the English Baccalaureate as a performance indicator, which identifies a set range of subjects on the curriculum that are eligible to assess students' - and therefore schools' academic achievements. Arguably, the omission of Religious Education from the English Baccalaureate has further undermined the status of religion in Catholic schools.

Askew (2013), reflecting on curriculum reform in the Australian context, considers that, potentially, the development of a national curriculum provides both threats and opportunities for Catholic schools. The decision to develop a national curriculum challenges Catholic schools to consider to what extent, if at all, the curriculum they offer can be considered distinctive. In this light, the question is how far Catholic schools within the maintained system of education can continue to sustain distinctive Catholic values. It is the question of values that I shall consider next.

\section{Values}

As indicated earlier, a school's curriculum is not just a collection of separate subjects but is founded on values. These may be conveyed implicitly or explicitly. In whatever way it is interpreted, the transmission of values is of fundamental importance for the curriculum of any school. Catholic schools, therefore, unreservedly offer an education that promotes distinctive values (Sullivan 2001).

Whilst the level of religious commitment may vary amongst pupils, Catholic schools have a responsibility to evangelise. Baum (1988, quoted by Morris 1995, p. 68) says:

... from the first moment that a student sets foot in a Catholic school, he or she ought to have the impression of entering a new environment, one illuminated by the light of faith and having its own unique characteristics. 
By the nature of a Catholic school, the curriculum implicitly and explicitly reflects values and virtues of the Catholic faith.

However, a Catholic interpretation of a distinctive value-driven curriculum is contested. The National Secular Society, for example, argues a case for the separation of religion and state and equal respect for everyone's human rights so that no one is either advantaged or disadvantaged on account of their beliefs (https:/ / www.secularism.org.uk/; accessed on 17 March 2021).

There is a suggestion in this argument that education should be 'neutral', i.e., free of values that are conveyed by religion. In a complex pluralist society, where there will be a multiplicity of views and opinions, however, what would constitute a 'value-free' education is open to debate.

Any education will embody values. Whether it is considered to be a repressive or a subversive activity or a source of enlightenment, education will essentially be concerned with the transmission of values. G.K. Chesterton (quoted by Pring 1996, p. 57) expresses this eloquently when he points out that every education teaches a philosophy; if not by dogma then by suggestion, by implication, by atmosphere. Every part of that education has a connection with every other part. If it does not all combine to convey some general view of life, then it is not education at all.

The suggestion is that it is inevitable that, if it is to be effective, any curriculum should involve the transmission of values. It would be axiomatic, therefore, that no education can be value-free or 'neutral'.

All teaching involves the transmission of values, whether it is secular, or Marxist, or Islamic or Christian. Therefore, to propose - as some protagonists $\mathrm{do}^{4}$ - that community schools offer an education that is 'neutral' is misconceived. As Grace (2002b, p. 14) eloquently points out:

Secular schools ... are not ideologically free zones. Secularism has its own ideological assumptions about the human person, the ideal society, the ideal system of schooling and the meaning of human existence.

Whilst these ideological assumptions might not be formally included as a curriculum subject called 'secular education' as opposed to 'religious education', they do characteristically permeate the ethos and culture of state-provided secular schools and form a crucial part of their 'hidden curriculum'.

It is argued that it is the shared understanding of Christian beliefs in a Catholic school that gives it an advantage in developing and maintaining a coherent culture. ${ }^{5}$ It should come as no great surprise, then, that Church schools are often considered to be very effective schools. David Blunkett, Tony Blair's first education secretary, for example, was heard on many occasions at conferences to make remarks such as: 'If I were able to bottle church schools' ethos and success, and pass it round the whole system, I would do so. ${ }^{6}$ What did he mean by this? Morris (2010, p. 81) suggests it means that Christian schools reflect the long tradition of English education that sees schools as communities (with as much emphasis placed on their role in developing values and character as on the acquisition of skills and knowledge) being places in which youngsters learn about virtues, values and being a good citizen.

The implication is that Christian schools can be characterised by a discernible ethos or set of values and virtues. Whilst academic achievement is important, it is important to move beyond a narrow, utilitarian conception of the curriculum if young people are to be prepared for their future in society.

It would also be appropriate here to consider the words of Pope Benedict XVI (2010, p. 30). In his address to the 'Big Assembly' at St Mary's University College during his State visit to Britain:

A good school provides a rounded education for the whole person. And a good Catholic school, over and above this, should help all its students to become saints 
In the context of the curriculum of a Catholic school, the notion that teachers should be helping students to become saints provides a fundamental inspiration. The emphasis, is, in the first place, on students rather than on curriculum subjects. This resonates with the expression: 'teachers teach students, not subjects.'

The question that remains, therefore, is what is valued in Catholic education? In what way does the curriculum in Catholic schools offer an all-round experience that has its own character? If it is informed by distinctive educational values, what are they? Groome (1998, p. 107) explains that:

... the distinctiveness of Catholic education is prompted by the distinctive characteristics of Catholicism itself, and these characteristics should be reflected in the whole curriculum of Catholic school.

Religious and moral values should be located at the heart of the curriculum of a Catholic school. It follows, moreover, as Arthur $(2007$, p. 1) points out, that the aim of the Catholic school should be to

... enable students to achieve their complete dignity as persons in a relationship with Christ.

According to this view, religion cannot be separated or divorced from the rest of the curriculum, nor, at the same time, would religious education be seen as the raison d'etre of the Catholic school. The idea that the school subjects that make up the curriculum (excluding religious education) are value free and therefore somehow separate from the Catholic faith is clearly contrary to the Catholic worldview.

Evidently, therefore, it is adherence to Gospel values and virtues that will make a difference to the focus and content of the curriculum in a Catholic school. The distinctive nature of a Catholic school will be informed by Gospel values and virtues, which are articulated

... to provide for her children an education by virtue of which their whole lives may be inspired by the spirit of Christ.

(Pope Paul VI 1965, n.3)

From this point of view, Catholic schools need to provide a coherent theology of the curriculum that combines a relevant content with appropriate methods of teaching and learning. Significantly, Conway (2017, p. 351) explains:

Education is always and inevitably about formation whether we recognize this explicitly or not. It can never be considered purely in terms of the provision of facts or of mere information. This would represent a very truncated and impoverished understanding of education. Similarly, a particular understanding of the human person is always implied in every educational system and there cannot be any neutrality in this regard.

This notion will be developed later in the context of discipleship.

The ethos ${ }^{7}$ of Catholic schools will also reflect values that many who are not Catholic can share. The ethos of a school conveys its character both implicitly and explicitly. Thus, as Jamison (2013, p. 11) says:

... non-Catholic parents and pupils [are able] to embrace the ethos wholeheartedly in a way that is harder for them to do if you insist on having Catholic faith as the headline.

Ultimately, the curriculum of a school is influenced by its culture and ethos, which, in turn, is informed by its shared values, virtues, beliefs, symbols, behaviours and assumptions. This may be summarised in the often-used expression: 'It's the way we do things around here.' (Deal and Kennedy 1982) Indeed, this expression, as applied to the curriculum of a Catholic school, might capture what is meant by the word 'ethos.' Essentially, leaders, in supporting the distinctive ethos of Catholic schools, are challenged to maintain 
'mission integrity', which can be described as the matching of the rhetoric of Catholic educational principles with reality. Grace (2010, p. 8) defines mission integrity as,

...fidelity in practice and not just in public rhetoric to the distinctive and authentic principles of a Catholic education.'

For Catholic schools, mission integrity can be characterised as the realisation of their stated principles within the day-to-day experiences of the school. Grace (2016) argues that a Catholic school that is faithful to the values of Catholic education, as reflected in its customs, systems and routines, has 'mission integrity'. In contrast, he defines a school that has, whether intentionally or inadvertently, moved away in its practice from its essential values as suffering from 'mission drift'. 'All faith-based schools are vulnerable to mission drift over time, especially when the secular political and public worlds offer such schools extra resources, status and accolades of 'excellence', 'successful' and 'effective' if they meet the requirements of the state.' (Grace 2016, p. 167)

Catholic school leaders have a critical responsibility within the context of the curriculum that is offered to both protect and further develop the 'mission integrity' of their schools by remaining faithful to the distinctive and authentic values of Catholic education as pronounced in Church documents. Are the values promoted by the public statements of the school reflected in the actions and behaviours that are expressed across the curriculum? Does the rhetoric match the reality? If it does not, the school will be susceptible to 'mission drift', which reflects a shift from its core values and a divergence from its fundamental principles.

\section{Implications}

If the curriculum in a Catholic school is to be informed by Gospel values, in what way will this be demonstrated? How does a Catholic school promote Gospel values? Where is the evidence? In this respect, Arthur (2007, p. 12) argues that:

Although it may be convenient to speak of the 'religious' curriculum and the 'secular' curriculum in Catholic school, as though these were separate and distinct, in reality the curriculum as a whole, and every part of it, is religious, since there is nothing which does not ultimately relate to God.

In discussing the Catholic curriculum, then, it should be emphasised that it should be an integrated curriculum. In fact, subject teachers in all schools, not just Catholic schools, are expected to promote more than subject knowledge but also the spiritual and moral values of their schools-indeed schools are inspected on this. Equally, the responsibility for promoting the Catholic school curriculum should not be limited only to those who teach religious education but is the responsibility of all teachers in the Catholic school. Askew (2013, p. 58), for example, points out that according to Vatican II and the post-conciliar documents, there is, above all, a Catholic worldview that should influence the Catholic school's curriculum. This necessarily involves a more integrated view of all that is learnt in schools for Catholic schools should be committed to attempting a proper synthesis of religion and culture, faith and life.

The reflections at the beginning of this paper imply that there is a complementarity between the pursuit of faith and the pursuit of reason. In a Catholic school, faith and reason share a symbiotic relationship. As Pope John Paul II (1998, Fides et Ratio , Introduction) says:

Faith and reason are like two wings on which the human spirit rises to the contemplation of truth; and God has placed in the human heart a desire to know the truth-in a word, to know himself-so that, by knowing and loving God, men and women may also come to the fullness of truth about themselves.

Furthermore, he argues that, whilst faith without reason leads to superstition, reason without faith leads to nihilism and relativism. Pope Benedict XVI (2010) concurred with this, when he addressed parliamentarians in Westminster Hall: 
I would suggest that the world of reason and the world of faith-the world of secular rationality and the world of religious belief-need one another and should not be afraid to enter into a profound and ongoing dialogue, for the good of our civilisation.

This position, moreover, echoes the view of Jacques Maritain, who argued that education cannot be considered to be integrated if it does not fully embrace the spiritual dimension of human nature. Similarly, John Henry Newman (1852) says that,

... all branches of knowledge are connected together, because the subject matter of knowledge is intimately united in itself, as being the acts and the work of the Creator. ${ }^{8}$

Therefore, care is needed with the use of the term, 'Catholic curriculum', to avoid misinterpreting it as meaning 'Catholic maths', 'Catholic science' or 'Catholic geography'. Rather than discussing the question of a Catholic curriculum in these terms, it would be of greater benefit to consider each subject as being integrated together within a unified whole related to God and to consider that Catholic principles are pervasive throughout the curriculum. This resonates with the perspective of Congregation for Catholic Education (1997, n.14), who say,

...the various school subjects do not present only knowledge to be attained, but also values to be acquired and truths to be discerned.'

Jones and Barrie (2015, p. 129), too, remind us that the unifying principle of Catholic education that should inform the whole curriculum is,

... the integral development of the human person, a person only properly understood in relation to other people and in communion with God.

A curriculum that is Catholic (whether with an upper-case ' $C^{\prime}$ or a lower-case ' $c$ ') is comprehensive and open to diverse possibilities. As Sullivan (2001) rightly points out, Catholic schools are both distinctive and inclusive. Therefore, it should not, by definition, be restricted by a narrow, materialistic and utilitarian notion of acquiring knowledge.

This leads to two further considerations, which were introduced earlier. First, Catholic education implies that there is an emphasis on relationships rather than on curriculum subjects. In the Gospels, the basic idea of discipleship is evident in the ministry of Jesus. Whereas the Jewish custom was that a disciple would choose their own teacher, it was Jesus himself who took the initiative to call people to follow him. 'You call me 'Teacher' and 'Lord,' and rightly so, for that is what I am.' (John 13:13)

In one way or another, Jesus is referred to as a teacher on more than fifty occasions in the Gospels, where the emphasis is on a personal commitment and loyalty to Jesus, rather than on what was to be studied. This was a radically new approach to education.

A personal relationship between the teacher and the pupil is an intrinsic characteristic of Christian discipleship. The implication is that we teach pupils not subjects. The value of the individual is paramount. The focus is on the 'whole person'. ${ }^{9}$ In this sense, Jesus' approach is revolutionary, for he moved people away from the law and towards a personal and spiritual response in human relationships. Christian discipleship, then, in this sense, is characterised by the value placed on the individual as a person.

Second, whilst academic achievement is important, if we are to prepare children for their future in society, we must move beyond a narrow conception of the curriculum as a set of subjects on a timetable. The education of the whole person is an important component of the curriculum. (Catholic Bishops' Conference of England and Wales 1996, p. 3) The Catholic school's distinctive ethos, though it is difficult to quantify, must not only include but must also extend beyond academic subjects. The question that must be asked is whether personal relationships and interactions based on Christian values are also evident in the school curriculum. Thus, we are reminded of the statement attributed to St Francis of Assisi: 'Preach the Gospel at all times, and if necessary, use words.' 


\section{Summary}

Catholic schools claim to provide a distinctive education, which is reflected in the curriculum that they offer. The curriculum includes all planned activities that take place formally and informally inside and outside the school. (Kerr 1968, p. 160) Fundamentally, the distinctive nature of a Catholic school or college or academy must be informed by Gospel values and virtues. Ultimately, the mission of a Catholic school should be:

... to provide for her children an education by virtue of which their whole lives may be inspired by the spirit of Christ.

(Pope Paul VI 1965, n.3)

In Catholic schools, though, it can often be assumed that the distinctive nature of the curriculum that is provided will be experienced through the prevailing ethos as if by a process of osmosis. The experience of regular liturgies, masses, collective worship and prayer life contribute to sustaining a distinctive Catholic curriculum. It might also be considered that the presence of statues, crucifixes and iconography also enhance the spiritual and religious environment of the Catholic school. Accordingly, ethos in a Catholic school has been compared with a stick of Brighton rock whose label, which is embedded throughout its length, can be read at both ends of the stick. However, whilst the curriculum should not be considered as a straitjacket, there is an assumption that its Catholic nature will be 'caught not taught'. But is this enough?

There are complex social and political challenges that arise for leadership at all levels within Catholic schools. Manifestly, a Catholic school cannot claim to be Catholic if it does not profess Catholic values and virtues. Therefore, Grace (2013, p. 104), says, trenchantly, that there is

....an urgent need to strengthen the Catholic cultural content of the curriculum in general to prevent a process of incorporation into a secularised and technicised educational culture.

Arthur (2013, p. 83), however, has controversially maintained that, in his judgement, the Catholic school curriculum in England has already, effectively, 'been de-Catholicised'. Indeed, he concludes that,

today the typical English Catholic school curriculum is ... almost indistinguishable from its secular counterpart and that increasingly those who teach in and attend Catholic schools have no particular commitment to the official vision of Catholic education.

Whilst this view has been challenged by Holman (2013), Grace (2013, p. 99) is further concerned that Catholic educational institutions at all levels have failed to offer a curriculum provision that is committed to the formation of Catholic youth. A great opportunity for the dissemination of the counter-cultural social messages of the Church has, thereby, been lost despite the existence of valuable resources.

Clearly, then, there is an urgent need to refresh and rethink the idea of the Catholic curriculum. Indeed, Arthur $(2007$, p. 2) rightly asserts:

The central point remains that a school cannot be truly Catholic unless Catholicism and its values are diffused into the entire curriculum, methods, organisation and ethos of the school.

But how can school leaders mobilise the school constituency in order to sustain a Catholic school curriculum?

It may be contentious to put forward alternative models of how an authentic education might be understood in Catholic schools today, where market-driven, neo-liberal values militate against Gospel values. But in order to respond to the hegemony of a National Curriculum imposed by central government on schools, there is a need for leaders in Catholic education to provide a transparent Catholic perspective that permeates the curriculum. The notion of the 'permeation' of Catholic identity in a school is raised in an article by 
Grace (2013) and it implies the realisation of Gospel values in the everyday personal lives of staff and students. The aim is to inspire and enhance the lives of individuals within a Catholic school with a personal spirituality informed by faith.

It is possible to point to many examples of developments that have taken place in the curriculum of Catholic schools in recent years that have been inspired by their distinctive tradition. O'Keeffe and Zipfel (2007), for instance, provide examples of how initiatives with a discrete faith dimension in the subject of Citizenship have enriched and enhanced the curriculum of Catholic schools. Defined as formation for citizenship, these practical developments have permeated spiritual and moral aspects of Catholic experience within the curriculum, and have had a profound effect on young people.

Catholic schools need to consider seriously the implications of promoting the distinctive nature of both the formal and its informal curriculum. This can be illustrated from my own experience when, together with another teacher, we accompanied a group of young people and parents on a pilgrimage to Lourdes during the Octave of Easter. The trip exemplified the kind of extra-curricular activity that can enhance the spiritual and religious experience of young people in a Catholic school. On our return to school, the experience was marked, both formally and informally, in assemblies, displays and everyday conversations in the school. Topics related to the pilgrimage were constructed in $\mathrm{RE}$ lessons where presentations were produced. An event of this nature can be woven into the fabric of the curriculum of the school.

It is argued, too, that, in order to mitigate the pressures of a state-mandated curriculum, Catholic secondary schools should adopt formal educational programmes that would articulate distinctive Catholic values. Whittle (2015), for example, proposes that Catholic schools should introduce compulsory philosophy lessons into the curriculum. He argues that there is a responsibility for Catholic schools to appreciate the values and traditions of the culture of the Catholic community. The introduction of philosophy would consequently facilitate an understanding of a distinctive Catholic perspective in schools.

This is not a new idea. Dwyer (1993), too, referred to 'an evangelised curriculum', which proposed the inclusion of content and pedagogy that reflected Catholic perspectives to religiously inform students to discern critically. The proposal involved an evaluation of curriculum and pedagogy, and especially social justice, through a Catholic lens. (Riley and Danner-McDonald 2013) This could also be characterised as a process of ensuring that the curriculum of the school would be consistent with a Catholic philosophy of education.

Crucially, too, Grace (2013, p. 104) considers that the curriculum of a Catholic school would be enhanced not only by its worship, ethos and formal religious education, but by a total curriculum experience which integrates faith and learning through the agency of Catholic social teaching.

It is acknowledged that it is not only the marketisation of education that challenges the ethos of Catholic education. The societal challenges of religious secularisation and pluralisation have also affected teachers, parents and pupils within the social environment of the school. However, Grace (ibid) recommends that the introduction of a study of Catholic social teaching as a course in the Sixth Form of Catholic schools would be of value not only because of its distinctive subject matter but also because it would be a means of resisting a pervasive secular and utilitarian curriculum designed by government to meet economic requirements.

A catholic and holistic approach to the curriculum recognises the integrity of human beings. This is especially evident where it connects all three areas of learning: cognitive (head), affective (heart) and practical (hands). A coherent curriculum will integrate head, heart and hands. ${ }^{10}$ Where cognitive, affective and practical engagement in learning are fully expressed, the curriculum will then acknowledge that students learn, think, feel and act differently. As Christ says:

I have come that they may have life, and have it to the full. 
The promotion of a culture of head, heart and hands learning presents both a challenge and an imperative in Catholic schools.

Every part of the curriculum is religious because ultimately it relates to God. Clearly, critical discussion and research are needed with regard to practice, teaching materials, forms of worship and assembly, school rules and discipline in Catholic schools. Crucially, though, what makes Catholic schools distinctive is that the values that underpin the curriculum should explicitly arise from the teachings of Jesus Christ, because, as stated by the Sacred Congregation for Catholic Education (1977, n.34):

Christ is the foundation of the whole educational enterprise in a Catholic school.

Therefore, fundamentally and essentially, if, in a Catholic school, the whole purpose of the curriculum is to provide students with an understanding of the teachings of Jesus Christ, the presence of Christ should fully permeate, inspire and inform the Catholic school in every aspect of its life.

Funding: This research received no external funding.

Institutional Review Board Statement: Not applicable.

Informed Consent Statement: Not applicable.

Data Availability Statement: Not Applicable.

Conflicts of Interest: The author declares no conflict of interest.

\section{Notes}

1 In this satire on curriculum provision, following the extinction of the sabre-tooth tigers, attempts to revise the curriculum to meet new needs are met with strong opposition by traditionalists.

2 http://www.educationengland.org.uk/documents/speeches/1976ruskin.html (accessed on 19 May 2021).

3 The term 'neoliberalism' is open to a number of interpretations but here I refer to government policies that are characterised by economic liberalism, free-market capitalism and the deregulation of state influence.

4 For a reflection on this discourse see Halstead and McLaughlin (2005). Are faith schools divisive? In Cairns et al. (2005).

5 It should also be borne in mind that Catholic schools are part of a wider global network of education, which is informed by scripture and conciliar traditions. It is interesting to consider that Catholic schools make significant contributions to education in countries that are not Catholic. In Jaffna, in Sri Lanka, for example, St Patrick's College is a leading and highly regarded aided private Catholic boys' school. The college was founded by the Irish missionary Monsignor Orazio Bettacchini in 1850. It has long played its part in the wider community by providing shelter and assistance to displaced families during times of need. There are about 120 teachers at the college, of whom $70 \%$ are Catholics. Amongst the students, $78 \%$ are Christians, of which $61 \%$ are Catholics, and the rest are Hindus.

6 https://www.theguardian.com/education/2000/dec/12/schools.theguardian (accessed on 19 May 2021).

7 Arthur (2007, p. 12) says that the Catholic Bishops of England and Wales consider ethos to be 'synonymous with and inseparable from its curriculum'.

8 https://www.newmanreader.org/works/idea/discourse5.html (accessed on 25 May 2021).

9 This principle is highlighted by the Catholic Bishops' Conference of England and Wales (1996, p. 3) when it talks of 'The Education of the Whole Person'.

10 As Pope Francis (2015) advises: 'There are three languages: head, heart, and hand. Education must pass through these three pathways. We must help them to think, feel what is in their hearts, and help them in doing. So these three languages must be in harmony with each other.' (Congregation for Catholic Education, World Congress Final Communique (21 November 2015): https://translate.google.co.uk/translate?hl=en\&sl=fr\&u=http://www.vatican.va/content/francesco/fr/speeches/20 15/november/documents/papa-francesco_20151121_congresso-educazione-cattolica.html\&prev=search\&pto=aue (accessed on 27 June 2021).

\section{References}

Arthur, James. 2007. Can There Be a Catholic School Curriculum? Renewing the Debate. London: University of London, Centre for Research and Development in Catholic Education.

Arthur, James. 2013. The de-Catholicising of the curriculum in English Catholic Schools. International Studies in Catholic Education 5: 83-98. [CrossRef]

Askew, Mark J. 2013. The idea of Catholic curriculum and curriculum reform in Australia. International Studies in Catholic Education 5: 53-67. [CrossRef] 
Baum, W., ed. 1988. The Religious Dimension of Education in a Catholic School. London: Catholic Truth Society.

Benjamin, Harold. 1939. The sabre-tooth curriculum. In The Curriculum: Context, Design and Development. Edited by Richard Hooper. Edinburgh: Oliver and Boyd.

Cairns, Jo, Roy Gardner, and Denis Lawton, eds. 2005. Faith Schools: Consensus or Conflict? London and New York: RoutledgeFalmer. Catholic Bishops' Conference of England and Wales. 1996. Principles, Practices and Concerns. London: Catholic Education Service.

Congregation for Catholic Education. 1997. The Catholic School on the Eve of the Third Millennium. London: CTS.

Conway, Eamonn. 2017. Why faith schools matter and the challenges of divestment. The Furrow 68: 350-60. Available online: https:/ / www.jstor.org/stable/44738571 (accessed on 10 October 2021).

Davis, Robert. 1999. Can There Be a Catholic Curriculum? In Catholic Education: Inside Out, Outside In. Edited by James Conroy. Dublin: Veritas/Lindisfarne.

Davis, Robert A., and Leonard Franchi. 2013. A Catholic curriculum for the twenty-first century? International Studies in Catholic Education 5: 36-52. [CrossRef]

Deal, Terrence E., and Allan A. Kennedy. 1982. Corporate Cultures. Reading: Addison-Wesley.

Dwyer, Barry. 1993. Catholic Schools: Creating a New Culture. Brunswick: E.J. Dwyer (Australia) PTY Ltd.

Education Reform Act. 1988. London: HMSO.

Education Scotland. 2004. A Curriculum for Excellence-The Curriculum Review Group. Edinburgh: The Scottish Executive.

Gleeson, Jim. 2015. Critical challenges and dilemmas for Catholic Education Leadership internationally. International Studies in Catholic Education 7: 145-61. [CrossRef]

Grace, Gerald. 1997. School Leadership: Beyond Educational Management. London and Washington: The Falmer Press.

Grace, Gerald. 1998. Realizing the mission: Catholic approaches to school effectiveness. In School Effectiveness for Whom? Challenges to School Effectiveness and School Improvement Movements. Edited by Roger Slee, Gaby Weiner and Sally Tomlinson. London: RoutledgeFalmer, pp. 117-27.

Grace, Gerald. 2001. The State and Catholic Schooling in England and Wales: Politics, ideology and mission integrity. In Oxford Review of Education. Oxford: Routledge, vol. 27, no. 4. pp. 489-500.

Grace, Gerald. 2002a. Catholic Schools: Missions, Markets \& Morality. London: Routledge.

Grace, Gerald. 2002b. Catholic Education in England and Wales. In Contemporary Catholic Education. Edited by Hayes Michael and Gearon Liam. Leominster: Gracewing.

Grace, Gerald. 2010. Mission Integrity: Contemporary Challenges for Catholic School Leadership. Paper presented at ACU: 5th International Conference on Catholic Educational Leadership, Sydney, Australia, 2-4 August.

Grace, Gerald. 2013. Catholic social teaching should permeate the Catholic secondary school curriculum: An agenda for reform. International Studies in Catholic Education 5: 99-109. [CrossRef]

Grace, Gerald. 2016. Faith, Mission and Challenge in Catholic Education: the selected works of Gerald Grace. Abingdon and New York: Routledge.

Groome, Thomas. 1998. Educating for Life. Allen: Thomas More Press.

Halstead, J. Mark, and Terence McLaughlin. 2005. Are faith schools divisive? In Faith Schools: Consensus or Conflict? Edited by Roy Gardner, Denis Lawton and Jo Cairns. London and New York: RoutledgeFalmer.

Holman, Michael. 2013. Why Catholic Schools Matter. In The Tablet. London: Tablet Publishing Company, pp. 58-59.

Jamison, Christopher. 2013. 'God has created me to do him some definite service' (Cardinal Newman): Vocation at the heart of the Catholic curriculum. International Studies in Catholic Education 5: 10-22. [CrossRef]

Jones, David A., and Stephen Barrie. 2015. Thinking Christian Ethos: The Meaning of Catholic Education. London: CTS.

Kelly, A. Vic. 2009. The Curriculum: Theory and Practice, 6th ed. London: Sage.

Kerr, John F. 1968. Changing the Curriculum. London: University of London Press.

Lawton, Denis. 1989. Education, Culture and the National Curriculum. London, Sydney, Auckland and Toronto: Hodder and Stoughton.

Lawton, Denis. 2000. Values and Education: A curriculum for the twenty-first century. In Values and the Curriculum. Edited by Jo Cairns, Roy Gardner and Denis Lawton. London: University Institute of Education.

Morris, Andrew B. 1995. The Catholic School Ethos: Its effect on post-16 student academic achievement. Educational Studies 21: 67-83. Available online: http://xm8pe9xp3w.search.serialssolutions.com/?id=doi:10.1080\%2F0305569950210106\&sid=literatum\% 3Atandf\&genre $=$ article\&aulast $=$ Morris $\&$ date $=1995 \&$ atitle $=$ The + Catholic + School + Ethos $\% 3 \mathrm{~A}+\mathrm{its}+$ effect + on + post $\% \mathrm{E} 2 \% 80 \% 90$ $16+$ student+academic+achievement\&jtitle=Educational+Studies\&title=Educational + Studies $\&$ volume=21\&issue $=1 \&$ spage $=67$ \&epage $=83 \&$ issn $=0305-5698$ (accessed on 21 October 2021).

Morris, Andrew B. 2010. Parents, pupils and their Catholic schools: evidence from school inspections in England 2000-2005. International Studies in Catholic Education 2: 80-94. [CrossRef]

Newman, John Henry. 1852. The Idea of a University. Notre Dame: University of Notre Dame Press.

Newsam, Peter. 2013. Towards a totalitarian education system in England: Looking at the Academy question in a longer policy context. Journal of Beliefs E Values 34: 312-17.

O'Keeffe, Bernadette, and Richard Zipfel. 2007. Formation for Citizenship in Catholic Schools. Chelmsford: Matthew James Publishing. Pope Benedict XVI. 2010. Heart Speaks Unto Heart. Address to pupils at St Mary's University College. London: DLT. 
Pope Francis. 2015. World Congress Final Communique. November 21. Available online: https://translate.google.co.uk/translate?hl= en\&sl=fr\&u=http:/ / www.vatican.va/content/francesco/fr/speeches/2015/november/documents/papa-francesco_20151121 _congresso-educazione-cattolica.html\&prev=search\&pto=aue (accessed on 21 October 2021).

Pope John Paul II. 1998. Fides et Ratio. London: CTS, Available online: https://www.vatican.va/content/john-paulii/en/encyclicals. index.html (accessed on 1 September 2021).

Pope Paul VI. 1965. Gravissimum educationis [Declaration on Christian Education]. Available online: https:/ /www.vatican.va/archive/hist_ councils/ii_vatican_council/documents/vatii_decl_19651028_gravissimum-educationis_en.html (accessed on 1 September 2021).

Pring, Richard. 1976. Knowledge and Schooling. London: Open books.

Pring, Richard. 1996. Markets, Education and Catholic Schools. Edited by T. H. McLaughlin, J. S. J. O'Keefe and B. O'Keeffe. London and Washington: The Falmer Press.

Pring, Richard. 2004. Philosophy of Education: Aims, Theory, Common Sense and Research. London: Continuum.

Pring, Richard. 2005. Faith Schools-Can they be justified? In Faith Schools: Consensus or Conflict? Edited by Roy Gardner, Denis Lawton and Jo Cairns. London: Routledge Falmer, pp. 51-60.

Pring, Richard. 2012. The Life and Death of Secondary Education for All: Dream or Reality? London: Routledge.

Pring, Richard. 2020. Challenges for Religious Education: Is There a Disconnect between Faith and Reason? Abingdon and New York: Routledge.

Riley, Maria, and Kerry Danner-McDonald. 2013. Seeing the world anew: Educating for a just and sustainable future: New perspectives for a Catholic curriculum. International Studies in Catholic Education 5: 23-35. [CrossRef]

Sacred Congregation for Catholic Education. 1977. The Catholic School. London: CTS.

Stenhouse, Lawrence. 1978. An Introduction to Curriculum Research and Development. London: Heinemann.

Sullivan, John. 2001. Catholic Education: Distinctive and Inclusive. Dordrecht: Kluwer Academic Publishers.

The National Secular Society. 2021. Campaign for Secular Education. Available online: https://www.secularism.org.uk/education/ (accessed on 30 March 2021).

Tyler, Ralph W. 1949. Basic Principles of Curriculum and Instruction. Chicago: University of Chicago Press.

Whittle, Sean. 2015. Philosophy in Schools: A Catholic Perspective. Journal of Philosophy in Education 49: 590-606. [CrossRef] 